British Journal of Education

Vol.8, Issue 2, pp.13-21, February 2020

Published by ECRTD- UK

Print ISSN: ISSN 2054-6351

Online ISSN: ISSN 2054-636X

\title{
EDUCATION FOR SUSTAINABLE DEVELOPMENT AND TEACHING BIODIVERSITY IN THE CLASSROOM OF THE SCIENCES OF THE MOROCCAN SCHOOL SYSTEM: A CASE STUDY BASED ON THE MINISTRY'S GRADES AND SCHOOL CURRICULA FROM PRIMARY TO SECONDARY SCHOOL AND QUALIFYING
}

\author{
Asma Id Babou', Omar Jiyed ${ }^{1}$, Bouchta El Batri' ${ }^{1}$, Lhoussaine Maskour ${ }^{1}$, \\ El Mostapha Aouine ${ }^{2}$, Anouar Alami ${ }^{1 *}$ and Moncef Zaki ${ }^{1}$ \\ ${ }^{1}$ Interdisciplinary Research Laboratory in Didactics of Science and Technology, \\ LIRDIST, Faculty of Sciences Dhar El Mahraz, Sidi Mohammed Ben Abdellah \\ University, P.B. 2626, Fez 30000, Morocco. \\ ${ }^{2}$ Applied Human Sciences Laboratory, Faculty of Letters and Human Sciences, Sais- \\ Fes, Sidi Mohammed Ben Abdellah University, P.B. 2626, Fez 30000, Morocco \\ *Corresponding author: E-mail: anouar.alami@usmba.ac.ma
}

\begin{abstract}
Biodiversity education increases human awareness in order to maintain the services provided by natural ecosystems. Hence, the interest in implementing educational projects targeting biodiversity education. However, it is important to integrate this concept into school curricula. Although it is a seemingly complex concept, biodiversity is now considered an indicator of sustainable development and is of strong educational interest. Education for sustainable development can be provided through science education on the concept of biodiversity. Thus, this chapter is reserved for qualitative and qualitative analyses in which we present the place of education for sustainable development and the concept of biodiversity in our science education curricula.
\end{abstract}

KEYWORDS: biodiversity, science education, life and earth sciences, education for sustainable development, Moroccan school curricula.

\section{INTRODUCTION}

The 21st century is witnessing an international movement of school reforms through improved curricula and syllabic. The aim is to ensure learning around objects and phenomena that affect the daily lives of learners in order to develop skills and ecoresponsible behavior (Lange, 2011). In other words, it is a question of establishing learning that makes it possible "to improve the quality of human life while respecting the carrying capacities of the ecosystems that shelter us" (Ouvrard \& Stenger, 2018), thus learning that makes it possible to ensure the sustainable development of the environment and society.

According to the National Education and Training Charter (COSEF, 1999), sustainable development (SD) is "a development process that meets the needs of the present without compromising those of future generations". According to Article 31 of the new Moroccan Constitution (2011), "The State, public institutions and local authorities shall 
Vol.8, Issue 2, pp.13-21, February 2020

Published by ECRTD- UK

Print ISSN: ISSN 2054-6351

Online ISSN: ISSN 2054-636X

work to mobilize all available means to facilitate equal access of citizens to the conditions enabling them to enjoy the right to sustainable development. Furthermore, SD is presented either as a scientific standard (Gros, 2012) or as a political or politicized standard (Villalba, 2009). Education for Sustainable Development (ESD) is, therefore, a choice of the education system in Morocco, which is in symbiosis with the national education policy. The relevance and degree of integration of ESD into our school curricula should then be examined.

Biodiversity is a complex concept (Barroca-Paccard, 2013). It can be discussed scientifically and socially, and it is also discussed its teaching at school. We can treat biodiversity in two ways (Lange and Martinand, 2010): biodiversity as biological diversity, and biodiversity as a component of sustainable development.This study is part of biodiversity education. The analysis conducted focuses on the formal science program at the elementary, high school and qualifying levels. It will make it possible to question the content of teaching and to raise the problems of coherence and compatibility between the different school levels.In order to comply with the official instructions and objectives of the Ministry of Education, aimed, among other things, at making students aware of the need to achieve sustainable development (COSEF, 1999), we conducted a quantitative and qualitative analysis to highlight the content of the program in terms and concept of biodiversity.

\section{METHODOLOGY}

\section{Corpus}

We conducted two types of qualitative and quantitative analyses on our corpus consisting of:

Table 1.

Official documents used in curriculum analysis.

\begin{tabular}{|l|l|l|}
\hline Title: & Year: & Publisher: \\
\hline $\begin{array}{l}\text { The White Book, Part II, Primary School } \\
\text { Curriculum (CECM, 2002) }\end{array}$ & June 2002 & $\begin{array}{l}\text { Curriculum and School } \\
\text { Life Directorate. }\end{array}$ \\
\hline $\begin{array}{l}\text { Life and Earth Sciences Curriculum - } \\
\text { Collegiate High School (DCVS, 2009) }\end{array}$ & August 2009 & $\begin{array}{l}\text { Directorate af } \\
\text { Curriculum and School } \\
\text { Life }\end{array}$ \\
\hline $\begin{array}{l}\text { Life and Earth Sciences Curriculum - } \\
\text { Qualifying High School (DCVS, 2007) }\end{array}$ & November 2007 & $\begin{array}{l}\text { Curriculum and School } \\
\text { Life Directorate. }\end{array}$ \\
\hline $\begin{array}{l}\text { Renovation of the primary curriculum of 1st, } \\
\text { 2nd, 3rd, 4th year. (DC, 2019) }\end{array}$ & May 2019 & Curriculum Directorate \\
\hline
\end{tabular}

\section{Lexicometric analysis}

It is a quantitative analysis based on the implementation of a corpus analysis from a word or a class of words in order to build an interpretation afterward. The presence and 
Vol.8, Issue 2, pp.13-21, February 2020

Published by ECRTD- UK

Print ISSN: ISSN 2054-6351

Online ISSN: ISSN 2054-636X

development of the term Biodiversity in Life and Earth Sciences (LES) curricula is a sign of the transposition of ESD in LES (Barroca-Paccard, 2013). We used CATMA 6.0.8 (https://app.catma.de/catma), a web-based application for text annotation, analysis, and visualization. This application supports the analysis of documents written in the Arabic language in our corpus.

\section{Thematic analysis}

It is a qualitative approach based on an attentive and exhaustive reading of the corpus, making it possible to mark and code the textual elements of what we have called "the dimensions to biodiversity teaching".

It is possible to identify a certain number of epistemological elements leading to the identification of relationships between biodiversity and some old themes of the Life and Earth Sciences programs (LES) (Lhoste and Neighbour, 2013).

\section{RESULTS}

\section{Education for Sustainable Development in Official Documents}

A UNESCO report (2017), challenges us. He cites the importance of establishing an indicator that attempts to measure the degree to which countries are integrating ESD into their education systems. This indicator should not normally be limited to "signaling" or "mentioning" ESD in policies, curricula, teacher education, and student development, but should also "track" the share of time allocated to ESD in the timetables of different levels of education and "benchmark" the priority of ESD in several subjects in order to change the levels of ESD integration on a multi-level scale. According to the report, ESD is defined as follows: ESD empowers learners to make informed decisions and take responsible actions for environmental integrity, economic viability and just society for present and future generations while respecting cultural diversity. This falls within the field of lifelong learning and is an integral part of quality education.

However, the limitation of this indicator is that it does not measure and assess the learning outcomes achieved by learners after the implementation of ESD in the education system.Morocco has devoted a great deal of effort throughout the four successive education reforms to establish the principles of education for the environment and sustainable development (ESD).Aware of the high costs of environmental degradation and its impact on development, Morocco is constantly developing its national programs and sectoral strategies for environmental conservation and sustainable development (MDCE, 2014).Several multilateral agreements clearly reflect Morocco's commitment to education for sustainable development and its ratification of the three Rio conventions on biological diversity, climate change and the fight against desertification.

In 1979, the environment and sustainable development were introduced for the first time in the natural science curricula of secondary schools as educational activities, thus responding to the demographic and health constraints of the time.In the 1985 reform, 
Vol.8, Issue 2, pp.13-21, February 2020

Published by ECRTD- UK

Print ISSN: ISSN 2054-6351

Online ISSN: ISSN 2054-636X

the aim was to convince learners of the need to preserve an environmental balance by avoiding the abuse of natural resources and economic energies.In 1994, two years after the Earth Summit in Rio, the school curriculum was oriented towards a "pedagogy by objectives" by giving greater emphasis to the environmental dimension and sustainable development (Chafiqi \& Alagui, 2011).

Six years later, Morocco adopted the National Charter for Education and Training (COSEF, 1999), which advocates taking into account the natural environment of the school as a place for combating the various scourges of society: pollution, corruption, disease, malnutrition. Several articles in the Charter stress the importance of raising the authorities' awareness of the environmental issue and, above all, of the links between it and socio-economic development.

This evolution of school curricula, observed in the course of education reforms, attests to Morocco's concern to embark on the path of sustainable development in accordance with its international commitments. This provides citizens with the knowledge and motivation needed to streamline environmental management. Since the creation of the Mohammed VI Foundation for the Protection of the Environment (FM6E) (https://www.fm6e.org/), innovative programs and projects have been developed, notably the international program "Eco-Schools", which is fully in line with the Foundation's mission: Environmental Education.

In order to generalize and gradually introduce the program in primary schools, a partnership agreement was signed between FM6E and the Ministry of National Education on 24 April 2010, under the Presidency of Their Royal Highnesses Prince Moulay Rachid and Princess Lalla Hasnaa, on the occasion of the celebration of Earth Day.

This Programme aims to integrate environmental education into the school curriculum, and enables learners and the different actors in the school to build a concrete environmental project for the place they share. It is an in vivo experience, which will later enable them to convey and defend behaviors and lifestyles that are respectful of their environment. The program aims to enable teachers to integrate Environmental Education into their lessons by establishing links with the subjects they teach, to make learners aware of environmental issues, enabling them to become aware of the impact of their behavior on the environment and to promote Environmental Management practices through the involvement of local elected officials.

Since 2013, the Mohamed VI Foundation for the Protection of the Environment has signed a partnership with the Ministry of National Education and Vocational Training, following the global orientation to encourage the establishment of education on the global environment and sustainable development (ESDD). Morocco is part of the network of partners of the UNESCO Global Action Project for ESD through the Mohamed VI Foundation for the Protection of the Environment (2014). The latter is 
Vol.8, Issue 2, pp.13-21, February 2020

Published by ECRTD- UK

Print ISSN: ISSN 2054-6351

Online ISSN: ISSN 2054-636X

part of the global ESD community of practice, which is active in the area of "capacitybuilding for educators and trainers".

\section{Education for Sustainable Development in Ministerial Notes}

We chose to make an analysis of the contents of the ministerial notes published since 2015, to see whether the new reform of the 2015-2030 (CSEFRS, 2015) vision will infect the orientations of the Ministry of National Education. Thus, we deduce:

- A total absence of the term "education for sustainable development". On the other hand, there has been interesting in "human rights education" and "environmental education" since 2016;

- Diversification of educational activities promoted by the Ministry of National Education relating to "environmental education":

+ Charter for the Environment in Schools (2015);

+ Young Journalists for the Environment Contest (2017);

+ Ecological Schools (2017);

+ Awareness campaign on cleanliness education (2017).

\section{Biodiversity in school curricula}

Results of the lexicometric analysis

According to the lexicometric analysis of our corpus, using the CATMA 6.0.8 online application, the word "Biodiversity" is cited in the corpus with a frequency of zero.

The integration of the term "Biodiversity" as such in the body of the texts of the primary school science curricula and the LES subject of the college high school and qualifying Moroccan, is not yet updated.

\section{Results of the thematic analysis}

A reading of the content of science curricula is necessary to show how the concept of "Biodiversity" is taught. We have developed an analytical grid based on five dimensions to identify and code biodiversity education:

- Classification of living things;

- Ecology;

- Genetics and the concept of species;

- Theory of evolution;

- Human activities and behaviors. 
British Journal of Education

Vol.8, Issue 2, pp.13-21, February 2020

Published by ECRTD- UK

Print ISSN: ISSN 2054-6351

Online ISSN: ISSN 2054-636X

\begin{tabular}{|c|c|c|c|c|c|c|c|}
\hline $\begin{array}{l}\text { Dimension } \\
\text { Education }\end{array}$ & \multicolumn{2}{|c|}{ of Biodiversity } & $\begin{array}{l}\text { Classification } \\
\text { of the living }\end{array}$ & Ecology & $\begin{array}{l}\text { Genetics } \\
\text { and the } \\
\text { concept } \\
\text { of } \\
\text { species }\end{array}$ & $\begin{array}{l}\text { Theory } \\
\text { of } \\
\text { evolution }\end{array}$ & $\begin{array}{l}\text { Human } \\
\text { activities } \\
\text { and } \\
\text { behaviours }\end{array}$ \\
\hline \multirow[t]{6}{*}{ Primary } & \multicolumn{2}{|l|}{ 1st year } & + & + & - & - & + \\
\hline & \multicolumn{2}{|l|}{ 2nd year } & + & + & - & - & - \\
\hline & \multicolumn{2}{|l|}{ 3rd year } & + & + & - & - & - \\
\hline & \multicolumn{2}{|l|}{ 4th year } & + & + & - & - & + \\
\hline & \multicolumn{2}{|l|}{5 th year } & + & + & - & + & + \\
\hline & \multicolumn{2}{|l|}{ 6th grade } & - & - & - & - & - \\
\hline \multirow{3}{*}{$\begin{array}{l}\text { College } \\
\text { High } \\
\text { School }\end{array}$} & \multicolumn{2}{|l|}{ 1st year } & + & + & - & + & + \\
\hline & \multicolumn{2}{|l|}{ 2nd year } & - & - & + & - & - \\
\hline & \multicolumn{2}{|l|}{ 3rd year } & - & - & - & - & - \\
\hline \multirow{9}{*}{$\begin{array}{l}\text { Lycée } \\
\text { qualifying }\end{array}$} & \multirow{2}{*}{$\begin{array}{l}\text { Common } \\
\text { core }\end{array}$} & Sc. & + & + & - & - & + \\
\hline & & L. & - & + & - & - & + \\
\hline & \multirow{3}{*}{$\begin{array}{l}\text { 1st year } \\
\text { Bac }\end{array}$} & LES & - & - & - & + & - \\
\hline & & M./PC & - & - & + & + & + \\
\hline & & L. & - & - & + & - & - \\
\hline & \multirow{4}{*}{$\begin{array}{l}\text { 2nd } \\
\text { Year Bac }\end{array}$} & LES & - & - & + & + & - \\
\hline & & M. & - & - & + & + & + \\
\hline & & $\mathrm{PC}$ & - & - & + & - & - \\
\hline & & Sc. A. & - & - & + & - & + \\
\hline
\end{tabular}

Sc.: Science / L.: Humanities / LES: Life and Earth Sciences / M.: Mathematics / PC: Physics-Chemistry / Agronomy Sc.

From the above table, it can be deduced that the dimensions of Biodiversity education are spread out in the primary and high school college curricula and qualified as follows: The dimension of "classification of living things" and that of "ecology" have been dealt with in almost all levels of primary education, only in the first year of middle school and the common core of qualifying high school.

The approach linked to the dimensions of "genetics and the notion of species" and that of "theory of evolution" is organized in stages from the college high school to the high school qualifying especially in the second year for the scientific branches (LES, M., PC, Sc.A.).

Finally, only the dimension "Human activities and behavior" is of a special nature:

- It is only in the renewed 2019 primary school curricula that this aspect occupies an important place;

- $\quad$ For the college, it is treated only in the first year;

- $\quad$ For the qualifying high school, the stakes become higher for almost all branches combined.

The difficulties that can arise when dealing with the concept of biodiversity in these different dimensions can be noted. The treatment of the complexity of the notion of biodiversity should normally encourage a certain progression in the level of difficulty 
Vol.8, Issue 2, pp.13-21, February 2020

Published by ECRTD- UK

Print ISSN: ISSN 2054-6351

Online ISSN: ISSN 2054-636X

from primary school to qualifying high school. This progress must be made in different ways. First of all, the scientific aspect. Secondly, the pragmatic aspect.

\section{DISCUSSION}

This analysis shows us that the concept of biodiversity is implicitly taken into account in school curricula. The lack of integration into the programs is questioned. Moreover, this concept gives the impression of a dichotomy: on the one hand, a disciplinary vision marked by a classification approach of living and ecological, and on the other hand, a heritage vision where Man is presented as the manager of ecosystems. Faced with this, we will seek to assess the presence or absence of the creation of links between the knowledge constructed and the social aspects of the notion of biodiversity during its teaching in Moroccan classrooms.

The new impetus is being given to adopt new measures and to improve the quality of the Moroccan education system. In order to improve the educational process in our country, it is necessary to include it in the strategy of sustainable development outlined by the United Nations as a local societal solution. SD is an active education, using interdisciplinary approaches. It has the power to assist in the formation of a future citizen, capable of forming a personal judgment and acting accordingly.

This is a cultural mutation to be produced, hence the role of the school. Learners need to be strongly involved in ESD issues. Motivation is not sufficient for such an education. It will, therefore, be necessary to develop human activities rather than knowledge and motivation (Lange, 2017).At the political level, the state of ESD at the global level is being developed. The reality differs from country to country. The generalization of ESD is a "voluntarist" political decision. In the case of developing countries, education policy is 'imposed' by the World Bank. According to the UN's SD Agenda 2030 (Franc, Reynaud \& Hasni, 2013), Education ranks 4th on the list of 17 SD goals (SDOs) to be achieved by 2030. The attainment of these DOs must be considered as a whole by all the states of the world. The policies implemented within this framework must be coherent and at the national level, we currently have opportunities in Morocco that must be seized in order to make progress towards ESD. This is the NSDS, which enables the institutions concerned to work together to achieve the objectives of this strategy and SD in general.

\section{CONCLUSION}

It is thus important to invest in the development of the cognitive assessment of the concept of biodiversity in order to improve the performance of pupils so that their knowledge is transformed into know-how and behavior (UN, 2030 Agenda) that enables them to solve environmental problems. This will give rise to education for sustainable development. 
British Journal of Education

Vol.8, Issue 2, pp.13-21, February 2020

Published by ECRTD- UK

Print ISSN: ISSN 2054-6351

Online ISSN: ISSN 2054-636X

\section{References}

Lange, J. M. (2011). Penser l'éducation scientifique en termes de contribution à l'éducation au développement durable : l'exemple des sciences de la Vie et de la Terre [Thinking scientific education in terms of contribution to education for sustainable development: the example of life and earth sciences]. HAL.

Ouvrard, B., \& Stenger, A. (2018). Politiques environnementales et incitations : De la théorie à l'innovation empirique. ISTE Group.

COSEF. (1999). Commission Spéciale Éducation Formation (COSEF). Charte nationale d'éducation et de formation [National Education and Training Charter]. Rabat, Morocco. Retrieved from https://www.men.gov.ma/Fr/Pages/CNEF.aspx

SGG. (2011). Secretatiat général du gouvernement (SGG). La Constitution [The Constitution]. Série documentation juridique marocaine, édition 2011. Retrieved from http://www.sgg.gov.ma/Portals/0/constitution/constitution_2011_Fr.pdf

Gros, F. (2012). Une biologie pour le développement [Developmental biology]. EDP sciences.

Villalba, B. (2009). Appropriations du développement durable [Appropriations of sustainable development]: émergences, diffusions, traductions. Presses Univ. Septentrion.

Barroca-Paccard, M. Orange-Ravachol, D. and Guyon P. (2013). Education for sustainable development and diversity of life: the notion of biodiversity in life and earth sciences curricula.

Lange, J.-M. and Martinand, J-L. (2010). ESD Curriculum: Principles of Design and Development. Paper presented at the International Colloquium "Education for Sustainable Development and Biodiversity: Concepts, Vivid Questions, Tools and Practices", Digne les Bains (pp. 118-136).

CECM. (2002). Comités d'Examen du Curriculum Marocain (CECM). Livre blanc [White Book], partie 2 : Curriculum éducatif pour les deux cycles de l'enseignement primaire. Rabat, Morocco.

DCVS. (2009). Direction des Curriculums et de la Vie Scolaire (DCVS). Curriculum des Sciences de la Vie et de la Terre du secondaire collégial. Rabat, Maroc.

DCVS. (2007). Direction des Curriculums et de la Vie Scolaire (DCVS). Curriculum des sciences de la vie et de la terre secondaire qualifiant. Rabat, Maroc.

DC. (2019). Direction des Curriculums (DC). Rénovation du curriculum du primaire de 1ère ,2ème, 3ème, 4ème année. Rabat, Maroc.2019.

https://app.catma.de/catma/ 11/29/2019

Lhoste, Y. and Neighbour, C. (2013). Benchmarks for Teaching Biodiversity in the Science Classroom. RDST.107-134.

UNESCO. (2017). Institut de Statistique de L'UNESCO, Métadonnées relatives aux indicateurs mondiaux et thématiques pour l'ODD 4 et l'Éducation 2030, UNESCO, juillet 2017. http://uis.unesco.org/sites/default/files/documents/quality-factorstrengthening-national-data-monitor-sdg4-2018-fr.pdf 
British Journal of Education

Vol.8, Issue 2, pp.13-21, February 2020

Published by ECRTD- UK

Print ISSN: ISSN 2054-6351

Online ISSN: ISSN 2054-636X

MDCE. (2014). Ministère Délégué Chargé de l'Environnement (MDCE). Loi cadre ${ }^{\circ}$ 99-12 portant charte nationale de l'environnement et du développement durable, Bulletin officiel. $\mathrm{n}^{\circ} 6240 \mathrm{du} 20$ mars 2014. Rabat, Maroc. http://www.onhym.com/pdf/Environnement/loi_cadre_99\%2012.pdf

Chafiqi, F., \& Alagui, A. (2011). Réforme éducative au Maroc et refonte des curricula dans les disciplines scientifiques. Carrefours de l'éducation, (3), 29-50.

Fondation Mohammed VI pour la Protection de l'Environnement (FM6E) : https://www.fm6e.org/

CSEFRS. (2015). For a school of equity, quality and promotion. A strategic vision of reform 2015-2030 (Report 2015). Morocco: Higher Council for Education, Training and Scientific Research. Retrieved from https://www.csefrs.ma/wpcontent/uploads/2015/05/Re\%CC\%81 sume\%CC\%81-visionAnglais.pdf

Lange, J. M. (2017). Éducation au développement durable en milieu scolaire. Paris : L'Harmattan, 82-91

Franc, S., Reynaud, C., \& Hasni, A. (2013). Vers une éducation à la biodiversité: prise en compte des savoirs, de l'affectivité et des comportements. Éducation et socialisation. Les Cahiers du CERFEE, (33). DOI : 10.4000/edso.140

UN. (2015). United Nations. Transforming our world: the 2030 Agenda for Sustainable Development. (Online)

https://sustainabledevelopment.un.org/post2015/transformingourworld 